\title{
Analisis Hubungan Kecepatan Rerata Terhadap Kecepatan Permukaan Untuk Penentuan Kekasaran Dasar Pada Aliran Saluran Terbuka
}

\author{
D.A. Widayanti* \\ ${ }^{a}$ Departemen Teknik Sipil dan Lingkungan, Universitas Gadjah Mada, Yogyakarta, Indonesia, Indonesia \\ ${ }^{*}$ Corresponding author's e-mail: diyahayuwe21@gmail.com
}

Received: 27 May 2021; revised: 16 July 2021; accepted: 19 July 2021

\begin{abstract}
The flow velocity of a channel may be used to determine the value of n-Manning, which is the coefficient representing the ruggedness of a hydraulic in a channel. Because of the difficulties in determining the value of $n$-Manning accurately on the field, this study is aimed to analyze the correlation between the mean flow velocity of a channel $(\mathrm{U})$ and the flow velocity point $(\mathrm{u}(\mathrm{Vi}, \mathrm{dj})) \mathrm{with} \mathrm{d}=0.0 \mathrm{D}$; $0.2 \mathrm{D} ; 0.6 \mathrm{D}$ in order to determine the precise value of $\mathrm{n}$-Manning of a channel. Vi, the vertical $\mathrm{i}$ represents the measurement point of transversal velocity (b/B), dj represents coordinate of the depth value of the flow. In conducting the study, the researcher analyzed the ratio between the mean flow velocity of a channel $(U)$ towards the flow velocity point $(u(V i, d j))$ for certain types of channel namely the coefficient $\mathrm{k}$ value; it was being analyzed based on several positions of measurement of transversal velocity, b/B. The types of channel used were the natural channel/ rivers (the middle part of Opak River, the upstream of Opak River, and the Kuning River), the Mataram Channel turn, the non-uniform of the Mataram Channel, the laboratory turn channel, and the straight laboratory channel. The result of the analysis of the $\mathrm{k}$ value was used to calculate the value of n-Manning. The final result was then compared to the value of $\mathrm{n}$-Manning based on the empirical calculation. Based on the study, the result of the $\mathrm{k}$ value of $\mathrm{d}=0.0 \mathrm{D} ; 0.1 \mathrm{D} ; 0.2 \mathrm{D}$ dan $0.6 \mathrm{D}$ for the data on the edge channel $(b / B=0,25)$ shows the greater range value than the $k$ range value on the middle channel $(b / B=0,50)$. The $k$ value on the middle channel is stable or relatively equal in all of the determined channels. The n-Manning value based on the $\mathrm{k}$ value and the formula of empirical calculation shows the close range value, especially for the data of the rivers and the Mataram Channel. Meanwhile, the data of the laboratory channel shows that the n-Manning value based on the empirical calculation is lower than the nManning value based on the $\mathrm{k}$ value.
\end{abstract}

Keywords: the mean flow velocity, the surface flow velocity, the coefficient $k$ value, the ruggedness of Manning.

\begin{abstract}
Abstrak: Kecepatan aliran suatu tampang saluran dapat digunakan untuk menentukan nilai $n$-Manning, dimana nilai $n$-Manning merupakan koefisien yang merepresentasikan kondisi kekasaran hidraulik suatu penampang saluran. Dikarenakan tidak mudahnya menentukan nilai $n$ - Manning secara akurat di lapangan, pada penelitian ini dilakukan analisis hubungan antara kecepatan aliran rerata tampang $(U)$ dengan kecepatan aliran titik $\left(u\left(b_{i}, d_{j}\right)\right)$ dengan $d=0.0 D ; 0.1 D ; 0.2 D$ dan $0.6 D$ untuk penentuan nilai $n$-Manning pada suatu tampang saluran, dimana $b_{i}$ adalah koordinat lebar saluran, $d_{j}$ adalah koordinat kedalaman aliran, $D$ adalah kedalaman aliran. Pertama-tama dilakukan analisis rasio antara kecepatan aliran rerata tampang $(U)$ terhadap kecepatan aliran titik $\left(u\left(V_{i}, d_{j}\right)\right)$ untuk beberapa jenis kondisi saluran yang disebut nilai koefisien $k$; nilai tersebut dianalisis pada beberapa posisi pengukuan arah transversal saluran, $b / B$. Jenis saluran yang digunakan terdiri dari saluran alami/sungai (Sungai Opak bagian tengah, Sungai Opak bagian hulu, Sungai Kuning), Saluran Mataram berbelok, Saluran Mataram tidak seragam, Saluran Laboratorium Berbelok, dan Saluran Laboratorium lurus. Hasil analisis nilai $k$ tersebut selanjutnya digunakan untuk perhitungan nilai $n$-Manning. Hasil perhitungan nilai $n$-Manning tersebut selanjutnya dibandingkan dengan nilai $n$ - Manning dari hasil perhitungan rumus empirik. Hasil nilai $k$ yang diperoleh pada $d=0.0 D ; 0.1 D ; 0.2 D$ dan $0.6 D$ untuk data di tepi saluran $(b / B=0,25)$ rentang nilai yang dihasilkan lebih besar dibandingkan rentang nilai $k$ ditengah saluran $(b / B=0,50)$. Nilai $k$ pada bagian tengah saluran nilai yang dihasilkan lebih stabil atau relatif sama di semua jenis saluran yang ditentukan. Nilai $n$-Manning berdasarkan nilai $k$ dan rumus empirik rentang nilai yang dihasilkan cukup dekat, khususnya untuk data di sungai dan Saluran Mataram. Sedangkan untuk data di saluran laboratorium nilai $n$-Manning berdasarkan rumus empirik lebih kecil dibandingkan nilai $n$-Manning berdasarkan nilai $k$.
\end{abstract}

Kata kunci: kecepatan aliran rerata, kecepatan aliran permukaan, nilai koefisien $k$, kekasaran Manning.

\section{Pendahuluan}

Saluran terbuka merupakan aliran air dalam saluran dengan muka air bebas [1-3]. Berdasarkan karakteristik aliran air pada saluran terbuka dapat diperoleh beberapa parameter, salah satunya adalah kecepatan aliran. Kecepatan aliran di suatu tampang saluran dapat digunakan untuk menentukan nilai $n$-Manning [4-7]. Koefisien Manning merupakan koefisien yang mempresentasikan kondisi kekasaran hidraulik suatu penampang saluran [810]. Dalam penentuan nilai $n$-Manning yang akurat di lapangan dapat dikatakan tidak mudah. Hal tersebut dikarenakan kondisi saluran di lapangan tidak sama, dan tidak banyak literatur yang menjelaskan hal tersebut. Penentuan nilai koefisien kekasaran Manning dapat dilakukan dengan menggunakan data pengukuran distribusi kecepatan dan/atau kecepatan aliran rerata; dimana merupakan metode yang dapat menghasilkan nilai Manning secara akurat. Di lapangan, pengukuran kecepatan aliran biasanya dilakukan dengan menggunakan alat Propeller Current Meter, namun demikian seringkali ditemukan kendala seperti tidak tersedianya alat dan tidak ada tenaga ahli yang dapat menggunakan alat secara benar. Sehubungan dengan itu, pada penelitian ini akan dilakukan suatu analisis untuk mencari metode pengukuran yang lebih 
mudah dengan menggunakan peralatan sederhana yang berfungsi seperti pelampung seperti ranting, sobekan kertas, botol air minum kemasan, dan lain-lain, yang sangat mudah ditemukan di lapangan. Hasil pengukuran dengan menggunakan pelampung akan menghasilkan kecepatan aliran di permukaan atau di dekat permukaan. Berdasarkan hal tersebut sebelum menentukan koefisien Manning, akan dilakukan suatu analisis rasio kecepatan aliran rerata terhadap kecepatan aliran di permukaan atau disebut dengan nilai koefisien $k$. Kemudian hasilnya digunakan untuk menentukan nilai $n$-Manning suatu penampang saluran. Selanjutnya nilai $n$-Manning yang dihasilkan diperbandingkan dengan nilai $n$-Manning hasil dari rumus empirik. Oleh karena itu, penelitian ini bertujuan untuk mengetahui perbedaan hasil analisis nilai $k$ pada bagian tepi $(b / B=0,25)$ dan bagian tengah $(b / B=0,50)$ saluran serta membandingkan hasil perhitungan nilai $n$-Manning berdasarkan analisis nilai $k$ dengan nilai $n$-Manning berdasarkan perhitungan rumus empirik pada setiap jenis saluran yang ditentukan.

\subsection{Kecepatan Aliran Rerata Vertikal}

Kecepatan aliran rerata vertikal $\left(U_{i}\right)$ merupakan rata-rata dari data kecepatan aliran titik $(u(b, d))$ hasil dari pengukuran kecepatan aliran pada beberapa titik kedalaman vertikal $(d)$. Perumusan untuk menghitung kecepatan aliran rerata vertikal dalam satu kedalaman vertikal akan disajikan pada Persamaan 1.

$$
i=\frac{1}{d i} \int_{0}^{D} u(V i, d) d d
$$

dengan, $U_{i}=$ kecepatan aliran rerata vertikal $(\mathrm{m} / \mathrm{s}), u\left(V_{i}, d_{j}\right)$ $=$ kecepatan aliran titik pada vertikal $i(V i)$ dan koordinat $d$ $(\mathrm{m} / \mathrm{s}), d=$ koordinat kedalaman titik vertikal $(\mathrm{m})$, dan $D_{i}=$ kedalaman aliran total $(\mathrm{m})$.

\subsection{Kecepatan Aliran Rerata Tampang Saluran}

Kecepatan aliran rerata tampang $(U)$ merupakan data kecepatan yang mewakili suatu tampang saluran. Perumusan kecepatan aliran rerata tampang disajikan pada Persamaan 2.

$$
U i=\frac{1}{A} \int_{0}^{B} \int_{0}^{D} u(b, d) d d d b
$$

dengan, $U=$ kecepatan aliran rerata tampang $(\mathrm{m} / \mathrm{s}), u(b, d)$ $=$ kecepatan aliran titik pada koordinat $b$ dan $d(\mathrm{~m} / \mathrm{s}), b_{i}=$ koordinat lebar saluran $(\mathrm{m}), d i=$ koordinat kedalaman vertikal (m), dan $A=$ luasan tampang saluran $\left(\mathrm{m}^{2}\right)$.

\subsection{Nilai Koefisien $k$}

Nilai $k$ merupakan rasio kecepatan aliran rerata terhadap kecepatan aliran titik pada tiap jenis dan kondisi saluran. Untuk memperoleh nilai $k$ yaitu dengan cara membagi kecepatan rerata aliran (Persamaan 2) dengan kecepatan aliran titik. Perumusan nilai $k$ dapat dilihat pada Persamaan 3.

$$
k=\frac{U}{u(b i, d j)}
$$

dengan, $k=$ rasio kecepatan rerata tampang terhadap kecepatan aliran titik, $U=$ kecepatan aliran rerata tampang $(\mathrm{m} / \mathrm{s})$, dan $u\left(b_{i}, d_{j}\right)=$ kecepatan aliran titik $(\mathrm{m} / \mathrm{s})$.

\subsection{Koefisien Manning}

Pada tahun 1889 seorang insinyur Irlandia, Robert Manning mengemukakan sebuah rumus yang akhirnya diperbaiki menjadi rumus yang sangat dikenal, dapat dilihat pada Persamaan 4.

$$
U=\frac{1}{n} R^{\frac{2}{3}} S^{\frac{1}{2}}
$$

Dengan, $U=$ kecepatan rerata aliran $(\mathrm{m} / \mathrm{s}), R=$ jari-jari hidrolik (m), $S=$ kemiringan energi, dan $n=$ koefisien kekasaran.

\subsection{Kekasaran Komposit}

Kekasaran komposit merupakan suatu nilai yang mewakili kekasaran dasar yang berbeda yakni pada dasar dan dinding saluran atau sungai. Dalam penentuan kekasaran komposit, persamaannya memiliki tiga konsep dasar yang secara umum digunakan untuk menurunkan persamaan, yaitu:

1. Debit total dari suatu penampang adalah sama dengan penjumlahan debit semua pias.

2. Kecepatan rerata total dari suatu penampang adalah sama dengan penjumlahan kecepatan rerata semua pias.

3. Gaya hambat total dari suatu penampang adalah sama dengan penjumlahan gaya hambat semua pias.

\subsection{Nilai n-Manning Komposit}

Nilai n-Manning yang dimaksud merupakan nilai yang diperoleh dengan menggunakan pendekatan kecepatan aliran titik. Pengukuran dilakukan di setiap vertikal pada satu tampang saluran, maka diperlukan satu nilai n-Manning yang dapat mewakili sebuah tampang, dapat disebut dengan nilai n-Manning komposit. Nilai tersebut dapat diperoleh dengan menggunakan Persamaan 5 yang disubstituiskan pada persamaan n-Manning. untuk lebih jelasnya akan ditujukkan pada penjabaran di bawah ini. Persamaan nManning komposit:

$$
U=\frac{1}{n c} R^{\frac{2}{3}} S^{\frac{1}{2}}
$$

Mensubstitusikan Persamaan 3 ke dalam Persamaan 5, maka persamaannya menjadi:

$$
k . u(b, d)=\frac{1}{n c} R^{\frac{2}{3}} S^{\frac{1}{2}}
$$

Sehingga, persamaan $n_{c}$ menjadi:

$$
n c=\frac{1}{k \cdot u(b, d)} R^{\frac{2}{3}} S^{\frac{1}{2}}
$$

Dimana nilai $k$ diperoleh dari analisis regresi untuk tiap jenis saluran dan sungai. Selanjutnya, dari pengukuran di tiap vertikal dilakukan analisis $n_{c}$ dengan persamaan di atas sehingga diperoleh nilai $n_{c}$ rerata untuk tiap tampang dan sungai tersebut. 


\section{Metode Penelitian}

Data yang digunakan untuk analisis dalam penelitian ini adalah data pengukuran yang diperoleh dari saluran laboratorium (lurus dan belokan), data dari saluran irigasi Mataram (lurus dan belokan) dan data sungai, yang diperoleh sebelumnya. Data laboratorium diperoleh dari Laboratorium PS-IT UGM (saluran lurus) (Andayono, 2003) dan dari Labratorium Hidraulika, DTSL FT UGM (saluran belokan/menikung) (Sumiadi, 2014) [11]. Untuk data Saluran Irigasi Mataram, 2 jenis data, yaitu data pengukuran pada saluran berbelok/menikung (Maini, 2016) [12] dan saluran tidak seragam (Afianto, 2016) [13]. Untuk data sungai diperoleh dari Sungai Opak bagian tengah (Nugroho, 2019) [14], Sungai Opak bagian hulu, dan Sungai Kuning (Kiptiah, 2016) [15].

\section{Hasil dan Pembahasan}

\subsection{Analisis Nilai Koefisien $k$}

Dengan menggunakan Persamaan (3.3) dapat diperoleh nilai $k$ pada masing-masing jenis saluran dengan koordinat kedalaman $d=0,0 D ; 0,1 D ; 0,2 D$ dan $0,6 D$. Pada analisis nilai $k$ yang dilakukan akan diketahui perbedaan nilai tersebut di bagian tepi saluran dan bagian tengah saluran. Maksud dari nilai $k$ pada bagian tepi saluran yaitu nilai $k$ yang berada pada area 0,25 dari lebar saluran baik sisi kiri maupun sisi kanan saluran $(b=0,25 B)$. Sedangkan arti dari nilai $k$ pada bagian tengah saluran yaitu nilai $k$ yang berada pada area 0,50 dari lebar saluran dan berada di tengah saluran $(b=0,50 B)$. Hasil analisis nilai $k$ tersebut dapat dilihat pada Tabel 1 dan Tabel 2.

Tabel 1. Rekapitulasi nilai $k$ di bagian tepi saluran $(b=0,25 B)$ pada masing-masing jenis saluran

\begin{tabular}{ccccc}
\hline \multirow{2}{*}{ Jenis Saluran } & \multicolumn{3}{c}{ Nilai $k$} \\
\cline { 2 - 5 } & $d=0,0 D$ & $d=0,1 \mathrm{D}$ & $d=0,2 D$ & $d=0,6 \mathrm{D}$ \\
\hline Sungai Opak Tengah & $0,85-1,09$ & $0,87-1,10$ & $0,78-1,20$ & $0,90-1,24$ \\
\hline Sungai Opak Hulu & $0,59-1,77$ & $0,58-1,41$ & $0,58-1,12$ & $0,69-1,43$ \\
\hline Sungai Kuning & $0,60-1,44$ & $0,69-1,47$ & $0,69-1,26$ & $0,80-1,80$ \\
\hline Saluran Mataram Berbelok & 1,06 & 1,07 & 1,04 & 1,13 \\
\hline Saluran Mataram Tidak Seragam & 1,16 & 1,15 & 1,13 & 1,27 \\
\hline Saluran Laboratorium Berbelok & $0,66-1,10$ & $0,68-1,14$ & $0,63-1,03$ & $0,62-1,00$ \\
\hline Saluran Laboratorium Lurus & $0,84-1,37$ & $0,85-1,40$ & $0,81-1,33$ & $0,83-1,35$ \\
\hline
\end{tabular}

Tabel 2. Rekapitulasi nilai $k$ di bagian tengah saluran $(b=0,50 B)$ pada masing-masing jenis saluran

\begin{tabular}{ccccc}
\hline \multirow{2}{*}{ Jenis Saluran } & \multicolumn{3}{c}{ Nilai $\boldsymbol{k}$} \\
\cline { 2 - 5 } & $\boldsymbol{d}=\mathbf{0 , 0 D}$ & $\boldsymbol{d}=\mathbf{0 , 1 D}$ & $\boldsymbol{d}=\mathbf{0 , 2 D}$ & $\boldsymbol{d}=\mathbf{0 , 6 D}$ \\
\hline Sungai Opak Tengah & $0,70-0,83$ & $0,73-0,86$ & $0,72-0,79$ & $0,78-0,91$ \\
\hline Sungai Opak Hulu & $0,64-0,86$ & $0,64-0,82$ & $0,60-0,76$ & $0,64-0,89$ \\
\hline Sungai Kuning & $0,51-0,75$ & $0,53-0,74$ & $0,50-0.76$ & $0,50-0,92$ \\
\hline Saluran Mataram Berbelok & 0,83 & 0,84 & 0,83 & 0,92 \\
\hline Saluran Mataram Tidak Seragam & 0,74 & 0,74 & 0,73 & 0,81 \\
\hline Saluran Laboratorium Berbelok & $0,73-0,85$ & $0,73-0,88$ & $0,70-0,82$ & $0,68-0,84$ \\
\hline Saluran Laboratorium Lurus & $0,73-0,98$ & $0,73-1,00$ & $0,72-0,98$ & $0,76-1,05$ \\
\hline
\end{tabular}

Selanjutnya nilai $k$ tersebut dilakukan analisis terhadap jarak transversal suatu penampang saluran $(b / B)$ yang kemudian kedua data tersebut diplotkan kedalam grafik. Hasil dari analisis kedua data tersebut yang berupa grafik dapat dilihat pada Gambar 1 sampai dengan Gambar 3.

Berdasarkan Tabel 2 dan Tabel 3, serta Gambar 2 sampai dengan Gambar 4 di atas, dapat dilihat bahwa untuk nilai $k$ di setiap jenis saluran yang telah ditentukan pada bagian tepi saluran, rentang nilai yang dihasilkan lebih besar dibandingkan rentang nilai $k$ pada bagian tengah saluran, dengan nilai lebih kecil. Dan juga untuk nilai $k$ pada bagian tengah saluran nilai yang dihasilkan relatif sama. Dengan kata lain, pengukuran kecepatan menggunakan pelampung sebaiknya dilakukan di 0,50 dari lebar saluran/sungai atau pada bagian tengah saluran.

\subsection{Analisis Nilai n-Manning Komposit BerdasarkanNilai Koefisien $k$}

Dari hasil analisis nilai $k$ terhadap $b / B$ yang berupa persamaan regresi, persamaan tersebut digunakan untuk menentukan nilai $n$-Manning komposit yang berdasarkan analisis nilai $k$. Nilai $n$-Manning komposit ditentukan dengan menggunakan Persamaan (7) yang kemudian hasilnya dibandingkan dengan nilai $n$-Manning komposit dari perhitungan rumus empirik. Hasil dari nilai tersebut pada masing-masing jenis saluran dapat dilihat pada Tabel 3. 
REKOnSTRUKSI TADULAKO: Civil Engineering Journal on Research and Development, Vol. 2(2), September 2021

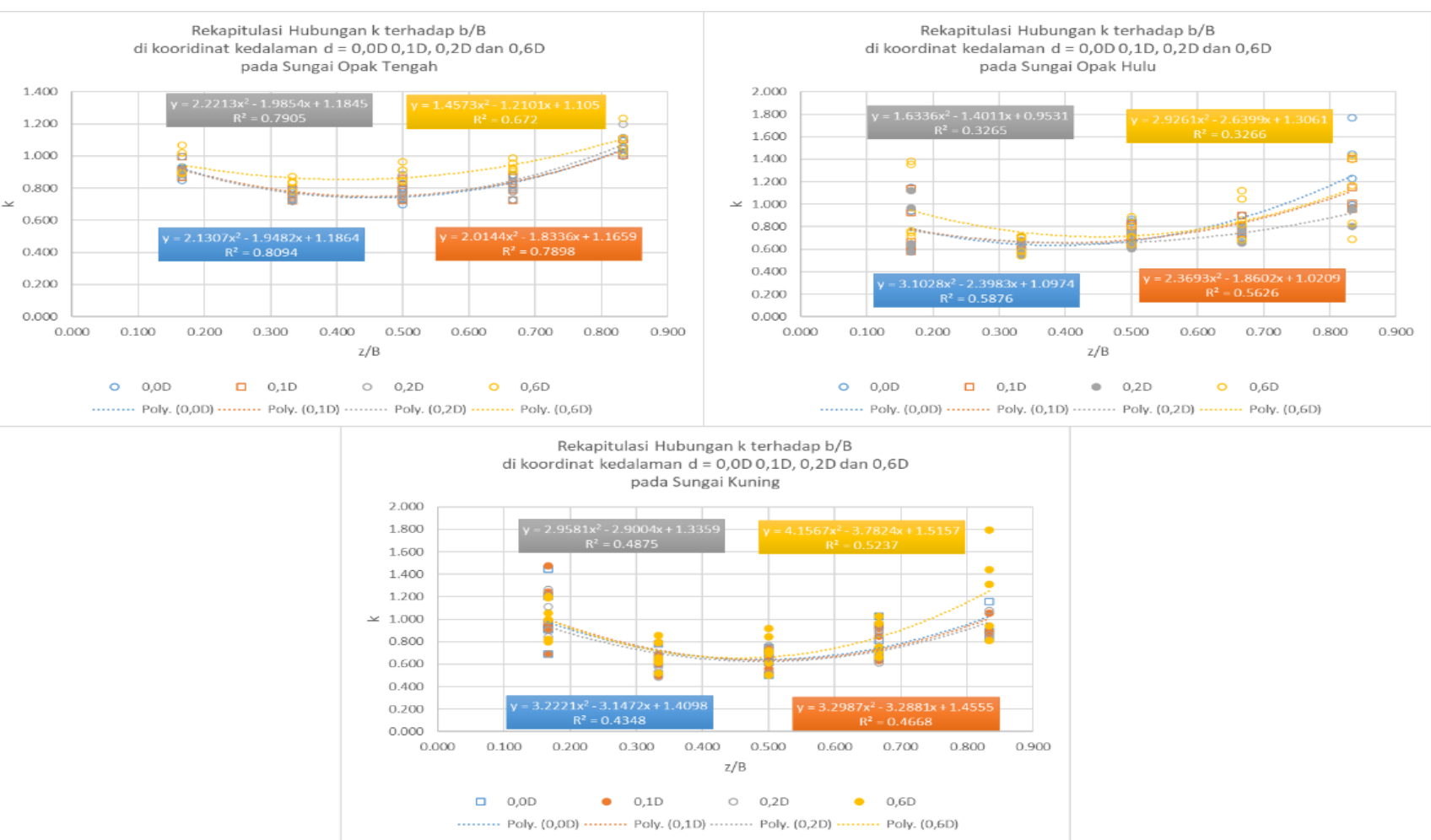

Gambar 1. Hasil nilai $k$ terhadap $b / B$ pada Sungai
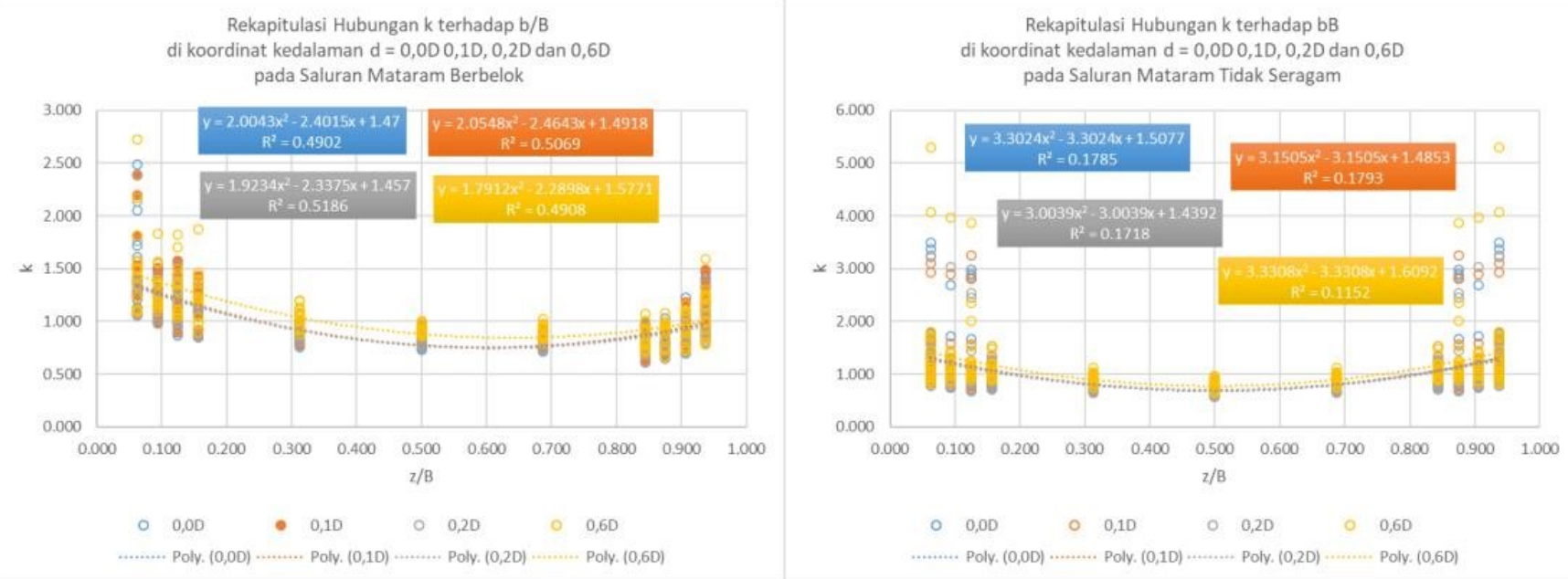

Gambar 2. Hasil nilai $k$ terhadap $b / B$ pada Saluran Mataram
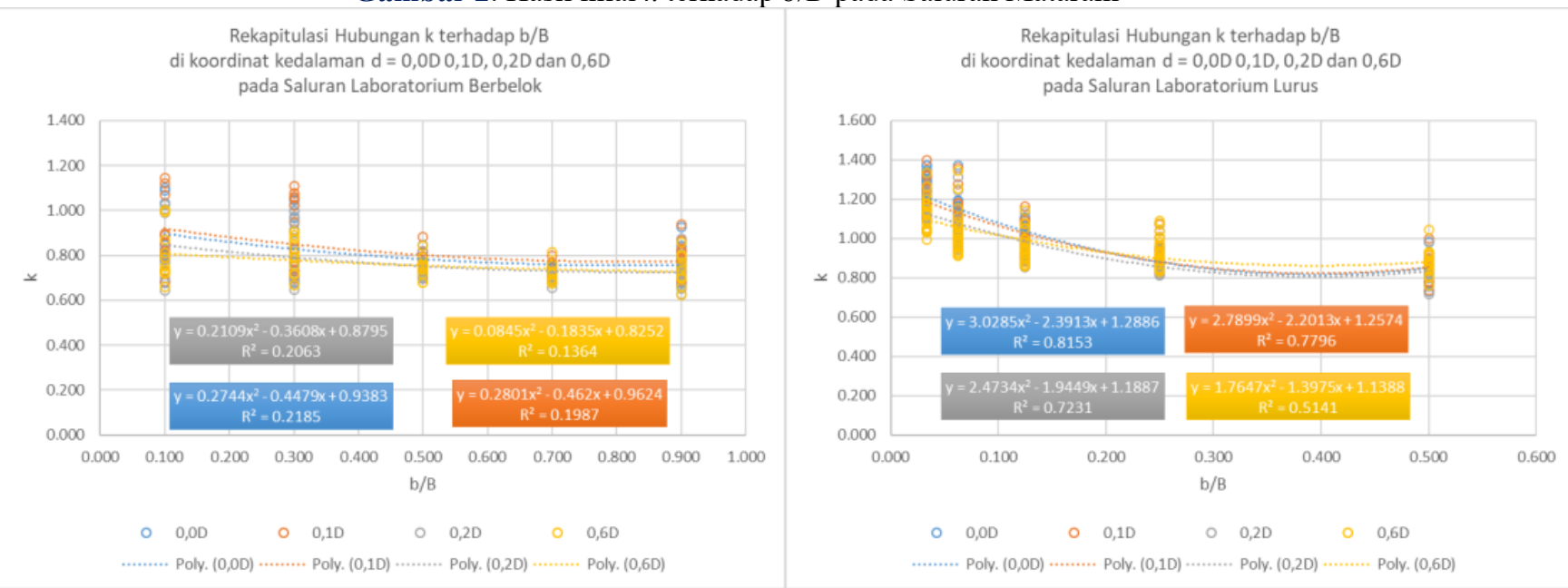

Gambar 3. Hasil nilai $k$ terhadap $b / B$ pada Saluran Laboratorium 
REKonSTRUKSI TADULAKO: Civil Engineering Journal on Research and Development, Vol. 2(2), September 2021

Tabel 3. Rekapitulasi Nilai n-Manning komposit pada Sungai.

\begin{tabular}{|c|c|c|c|c|c|c|}
\hline \multirow{2}{*}{\multicolumn{2}{|c|}{$\begin{array}{c}\text { Persamaan } n \text {-Manning } \\
\text { Komposit }\end{array}$}} & \multicolumn{5}{|c|}{ Nilai $n$-Manning Komposit } \\
\hline & & \multirow{2}{*}{$\begin{array}{c}\text { Sungai } \\
0,015-0,038\end{array}$} & \multirow{2}{*}{$\begin{array}{c}\begin{array}{c}\text { Selokan } \\
\text { Mataram } \\
\text { Berbelok }\end{array} \\
0,019-0,029\end{array}$} & \multirow{2}{*}{$\begin{array}{c}\text { Selokan } \\
\text { Mataram Tidak } \\
\text { Seragam }\end{array}$} & \multirow{2}{*}{$\begin{array}{c}\begin{array}{c}\text { Saluran Lab. } \\
\text { Berbelok }\end{array} \\
0,031-0,035\end{array}$} & \multirow{2}{*}{$\begin{array}{c}\begin{array}{c}\text { Saluran Lab. } \\
\text { Lurus }\end{array} \\
0,016-0,035\end{array}$} \\
\hline & $d=0,0 D$ & & & & & \\
\hline$n$-Manning & $d=0,1 D$ & $0,016-0,036$ & $0,020-0,028$ & $0,017-0,045$ & $0,030-0,035$ & $0,016-0,035$ \\
\hline nilai & $d=0,2 D$ & $0,017-0,038$ & $0,019-0,029$ & $0,017-0,047$ & $0,031-0,034$ & $0,016-0,035$ \\
\hline & $d=0,6 D$ & $0,017-0,036$ & $0,020-0,028$ & $0,017-0,051$ & $0,031-0,046$ & $0,016-0,036$ \\
\hline \multicolumn{2}{|c|}{ Cox } & $0,014-0,036$ & $0,015-0,027$ & $0,012-0,040$ & $0,009-0,014$ & $0,010-0,011$ \\
\hline \multicolumn{2}{|c|}{ Colebatch } & $0,014-0,036$ & $0,015-0,027$ & $0,012-0,040$ & $0,009-0,014$ & $0,010-0,011$ \\
\hline \multicolumn{2}{|c|}{ Horton-Einstein } & $0,014-0,036$ & $0,015-0,028$ & $0,012-0,040$ & $0,008-0,014$ & $0,009-0,011$ \\
\hline \multicolumn{2}{|c|}{ Felkel } & $0,009-0,035$ & $0,013-0,026$ & $0,011-0,037$ & $0,006-0,014$ & $0,009-0,011$ \\
\hline \multicolumn{2}{|c|}{ Pavlovskii } & $0,015-0,036$ & $0,016-0,028$ & $0,012-0,039$ & $0,009-0,014$ & $0,009-0,011$ \\
\hline \multicolumn{2}{|c|}{ Lotter } & $0,008-0,033$ & $0,013-0,023$ & $0,011-0,036$ & $0,006-0,012$ & $0,009-0,010$ \\
\hline \multicolumn{2}{|c|}{ Ida-Engelund } & $0,009-0,035$ & $0,014-0,025$ & $0,012-0,040$ & $0,007-0,014$ & $0,009-0,011$ \\
\hline \multicolumn{2}{|c|}{ Yen 1} & $0,014-0,036$ & $0,015-0,027$ & $0,012-0,038$ & $0,008-0,014$ & $0,009-0,011$ \\
\hline \multicolumn{2}{|c|}{ Yen 2} & $0,014-0,036$ & $0,015-0,028$ & $0,012-0,039$ & $0,008-0,015$ & $0,009-0,011$ \\
\hline \multicolumn{2}{|c|}{ Yen 3} & $0,014-0,035$ & $0,014-0,027$ & $0,012-0,038$ & $0,008-0,014$ & $0,009-0,011$ \\
\hline \multicolumn{2}{|c|}{ Krishnamurthy-Christensen } & $0,011-0,035$ & $0,014-0,026$ & $0,011-0,039$ & $0,007-0,014$ & $0,009-0,011$ \\
\hline
\end{tabular}

\section{Kesimpulan}

Dari hasil analisis data yang sudah dilakukan diperoleh beberapa kesimpulan sebagai berikut:

1. Nilai $k$ yang dihasilkan dari data kecepatan titik pada koordinat kedalaman $d=0,0 D ; 0,1 D ; 0,2 D$ dan $0,6 D$ di setiap jenis saluran yang telah ditentukan pada bagian tepi saluran $(b / B=0,25)$, rentang nilai yang dihasilkan lebih besar dibandingkan rentang nilai $k$ pada bagian tengah saluran $(b / B=0,50)$, dengan rentang nilai lebih kecil. Dan juga untuk nilai $k$ pada bagian tengah saluran nilai yang dihasilkan relatif sama. Dengan kata lain, pengukuran kecepatan menggunakan pelampung sebaiknya dilakukan di 0,50 dari lebar saluran/sungai atau pada bagian tengah saluran.

2. Nilai $n$-Manning komposit $\left(n_{c}\right)$ berdasarkan hasil nilai $k$ dan rumus empirik diperoleh rentang nilai yang cukup dekat, khususnya untuk data Sungai dan data Saluran Mataram. Sedangkan untuk data Saluran Laboratorium, nilai $n$-Manning komposit berdasarkan rumus empirik nilainya lebih kecil dibandingkan dengan nilai $n$ Manning berdasarkan nilai $k$.

\section{Daftar Pustaka}

[1] C. Ikhsan, "Analisis Distribusi Kecepatan Aliran Seragam Pada Saluran Terbuka Tampang Segiempat", Media Teknik Sipil, no. 16, p. 35, 2006.

[2] H. Putro, and J. Hadihardaja, "Variasi Koefisien Kekasaran Manning (n) pada Flume Akrilic pada Variasi Kemiringan Saluran dan Debit Aliran", Media Komunikasi Teknik Sipil, vol. 19, no. 2, p. 141, 2015.

[3] S. Kimi, "Pengaruh Jenis dan Kemiringan Dasar Saluran Terhadap Nilai Koefisien C Dengan
Persamaan Manning Berdasarkan Hasil Uji Laboratorium", Bearing : Jurnal Penelitian dan Kajian Teknik Sipil, vol. 4, no. 1, p. 1, 2015.

[4] M. Maini, D. Legono, and A.P. Laksitaningtyas, "Evaluasi Estimasi Koefisien Kekasaran Pada Eksperimen Model Fisik", Jurnal Ilmiah Desain \& Konstruksi, vol. 19, no. 1, p. 1, 2020.

[5] W.L. Nugraha, M.A. Maulana, W. Wardoyo, and S.D. Negara, "Analisis Sensitivitas Kecepatan Rata-rata Kedalaman dan Tinggi Muka Air terhadap Parameter Masukan Setting Model pada Saluran Berbelok $180^{\circ}$ dengan Menggunakan Program Bantu Delft3D”, Jurnal Aplikasi Teknik Sipil, vol. 19, no.1, p. 73, 2021.

[6] C. Sujatmiko, "Kajian Nilai Koefisien Hambat Pada Saluran Terbuka”, Jurnal Sains dan Inovasi, vol. 4, no. 1, p. 28, 2008.

[7] M. Maini and D. Legono, "Sensitivitas Hasil Uji Model Fisik Terhadap Perbedaan Penggunaan Angka Kekasaran n-Manning", FROPIL, vol. 9, no. 1, p. 1, 2021.

[8] O.B. Prismayuda, A. Purnama, and D. Najimuddin, "Analisis Distribusi Kecepatan Pada Saluran Terbuka (Study Kasus : Sungai Pelat, Desa Pelat)", Jurnal SainTekA, vol. 1, no. 1, p. 1, 2020.

[9] E. Harseno and S. Jonas, "Studi Eksperimental Aliran Berubah Beraturan Pada Saluran Terbuka Bentuk Prismatis", Majalah Ilmiah UKRIM, vol. 12, no. 2, p. 1, 2007.

[10] G.Y.D. Astuti and Feril Hariati, "Studi Karakteristik Aliran Pada Flume Saluran Terbuka di Laboratorium Teknik Sipil UIKA", vol. 5, no. 1, p. 16, 2016. 
[11] Sumiadi, Aliran Pada Saluran Menikung Dasar Rata dan Dasar Tergerus (Disertasi), Yogyakarta: Departemen Teknik Sipil dan Lingkungan, Fakultas Teknik, Universitas Gadjah Mada, 2014.

[12] M. Maini, Distribusi Konsentrasi Sedimen Suspensi pada Belokan Saluran Terbuka Tampang Trapesium. (Tesis), Yogyakarta: Departemen Teknik Sipil dan Lingkungan, Fakultas Teknik, Universitas Gadjah Mada, 2016.

[13] E.N. Afiato, Distribusi Kecepatan Aliran dan Konsentrasi Sedimen Suspensi pada Aliran Tidak Seragam (Studi Kasus Saluran Mataram Yogyakarta) (Tesis). Yogyakarta: Departemen Teknik Sipil dan Lingkungan, Fakultas Teknik, Universitas Gadjah Mada, 2016.
[14] D.A. Nugroho, Penentuan Kekasaran Dasar Berdasarkan Hasil Pengukuran Distribusi Kecepatan (Tugas Akhir), Yogyakarta: Departemen Teknik Sipil dan Lingkungan, Fakultas Teknik, Universitas Gadjah Mada, 2019.

[15] M. Kiptiah, Distribusi Kecepatan Aliran Sedimen Suspensi pada Sungai Alami (Tesis), Yogyakarta: Departemen Teknik Sipil dan Lingkungan, Fakultas Teknik, Universitas Gadjah Mada, 2016. 